\title{
Spasmolytic Effect of Papaya (Carica papaya L.) Leave Alkaloid on Isolated Rat Myometrial Contraction in vitro
}

\author{
Kitja Sawangjaroen ${ }^{1,2, *}$ and Kasorn Keereevong ${ }^{1}$ \\ ${ }^{1}$ Department of Pharmacology, Faculty of Science, Prince of Songkla University, Songkhla 90110, Thailand \\ ${ }^{2}$ School of Pharmacy, Walailak University, Nakhon Si Thammarat 80160, Thailand
}

("Corresponding author's e-mail: kitja.sa@wu.ac.th)

Received: 30 September 2020, Revised: 28 May 2021, Accepted: 28 June 2021

\begin{abstract}
This study aimed to investigate the action of crude alkaloid extract from papaya leaves (PA) on the isolated rat myometrium in vitro. The alkaloids were extracted from papaya leaves using conventional acid-base method. The myometrium strips were taken from female Wistar rats pretreated with diethylstilbestrol $(100 \mu \mathrm{g})$ for $24 \mathrm{~h}$ before the experiment. A preliminary experiment has shown that PA had no effect on myometrial contraction. However, PA $\left(10^{-6}-10^{-3} \mathrm{gm} / \mathrm{mL}\right)$ significantly inhibited myometrium contraction pre-contracted with a depolarizing solution in a concentration-dependent fashion. PA $\left(10^{-5}, 3 \times 10^{-5}\right.$ or $\left.10^{-4} \mathrm{gm} / \mathrm{mL}\right)$ or verapamil $\left(10^{-9}, 10^{-8}\right.$ and $\left.10^{-7} \mathrm{M}\right)$ were able to inhibit the myometrial contractile response to $\mathrm{CaCl}_{2}\left(10^{-5}-3 \times 10^{-2} \mathrm{M}\right)$ in $\mathrm{Ca}^{2+}$-free solution and cause a rightward shift of $\log$ concentration-response curve. PA also significantly inhibited myometrium contraction produced by oxytocin $(1 \mathrm{mU} / \mathrm{mL})$, ACh $\left(3 \times 10^{-5} \mathrm{M}\right)$ and $\mathrm{PGF}_{2 \alpha}\left(10^{-5} \mathrm{M}\right)$. Furthermore, propranolol $\left(10^{-7}\right.$ M) caused no effect on uterine relaxation induced by PA $\left(10^{-6}-10^{-3} \mathrm{gm} / \mathrm{mL}\right)$, although it inhibited uterine relaxation induced by isoproterenol $\left(10^{-10}-10^{-5} \mathrm{M}\right)$. These results indicated that PA was a uterine relaxant. Its mechanism of action may be unrelated to stimulation of $\beta_{2}$-adrenergic receptors of the uterus. This action may be contributed to mainly the $\mathrm{Ca}^{2+}$ influx, possibly through voltage-operated $\mathrm{Ca}^{2+}$ channel on the plasma membrane, and to a lesser extent by a rise in $\mathrm{Ca}^{2+}$ release from internal storage. However, the action of PA at intracellular sites, downstream of $\mathrm{Ca}^{2+}$ influx such as the contractile machinery of the myometrium, cannot be excluded.
\end{abstract}

Keywords: Carica papaya, Papaya alkaloids, Uterine contraction, Uterine relaxation

\section{Introduction}

Papaya (Carica papaya, L., Caricaceae) is a common plant cultivated in tropical countries. It is easily cultivated and widely used as food or dessert [1]. Various parts of this plant (fruit, leaves, seeds or latex) contain many biologically active compounds and has been used as medicinal herb in many areas of the world. Recent studies revealed that the compounds exhibit various pharmacological properties such as promoting the function of digestive system, anthelmintic, anti-amoebic, anti-inflammatory, wound healing, antifertility and contraceptive, antifungal, antibacterial, antitumor, antioxidant, anti-dengue and antimalarial $[1,2]$

Papaya leaves are abundant of biologically active constituents such as alkaloids (carpaine, pseudocarpaine and dehydrocapaine I and II), flavonoids (kaemferol and myricetin), phenolic compounds (ferulic acid, caffeic acid, chlorogenic acid), carotene, caproside, vitamin $\mathrm{C}$ and vitamin $\mathrm{E}$ [2,3]. These constituents exhibit medicinal properties such as antibacterial, antiviral, antitumor, anti-inflammatory, antifertility, abortifacient, hypoglycemic, hepatoprotective and wound healing $[3,4]$. Papaya leaf extract also alleviated menstrual pain probably related to the reduction in blood level of prostaglandin $F_{2 \alpha}$ in primary dysmenorrhea [5]. The latter effect could occur from one or more of its active constituents.

Carpaine is a principal alkaloid of papaya and present in various green parts of the plant [6]. Its actions were quite resembling to digitalis and emetine without most of their serious adverse effects. Carpaine and pseudocarpaine have been shown to have a depressive effect on the heart [7]. The uterus showed marked relaxation by this alkaloid [6]. More recent studies revealed antithrombocytopenic and antiplasmodial activity of this alkaloid which could be beneficial for the treatment of dengue fever and malaria $[8,9]$. 
Although, previous studies have demonstrated the pharmacological actions of carpaine, the mechanism of action of this alkaloid is poorly understood. In addition, carpaine is the most abundant alkaloid present in papaya leaves and possesses a uterine relaxing property. Papaya leaf extract have been shown its effect to relief menstrual pain. Carpaine and other alkaloids could work in concert with other active constituents of papaya leaf extract to ease the menstrual pain. This has led us to reinvestigate the effects of the alkaloid from papaya leaves, aiming to propose a mechanism of action of the alkaloid extract which has never been mentioned elsewhere.

\section{Materials and methods}

\section{Preparation of plant materials}

Papaya leaves $(20 \mathrm{~kg}$ ) were obtained from a papaya orchard in Ronpiboon District, Nakhon Si Thammarat Province, Thailand. They were examined by a botanist of Botany Section, Department of Biology, Prince of Songkla University. The leaves were cleansed and rinsed with distilled water, left to air-dry of excess water at ambient temperature in a well-ventilated room overnight. They were further dried at $50{ }^{\circ} \mathrm{C}$ until dryness in hot air oven. Leaf stalk and large veins were then separated from the green leaves and discarded. The remaining dried leaves were pulverized to powder $(2.2 \mathrm{~kg}$.) and used to extract alkaloids.

\section{Drugs and Chemicals}

Acetylcholine chloride, $( \pm)$-verapamil hydrochloride, DL-propranolol hydrochloride, $( \pm)$ isoproterenol hydrochloride, dimethylsulfoxide (DMSO) and diethylstilbestrol (DES) were obtained from Sigma Chemical Company. These chemicals, except DES were prepared as stock solutions in $0.1 \%$ ascorbic acid in distilled water (acetylcholine $10^{-1} \mathrm{M}$, propranolol $10^{-4} \mathrm{M}$, verapamil $10^{-4} \mathrm{M}$, and isoproterenol $10^{-1} \mathrm{M}$ ). Diethylstilbestrol was prepared for intraperitoneal injection by dissolving in olive oil ( $1 \mathrm{mg} / \mathrm{mL}$ ). Oxytocin (syntocinon) was purchased from Novartis and Pharmacia and PGF $2 \alpha$ (Dinoprost thromethamine) from Upjohn (Belgium). Papaya leave's alkaloid (PA) was prepared as a stock solution $(200 \mathrm{mg} / \mathrm{mL})$ by dissolving in dimethylsulfoxide for use in all experiments. The stock solutions were diluted to appropriate concentrations with physiological solutions before adding into the organ bath. The total concentration of dimethylsulfoxide in the organ chamber after cumulative addition of PA stock solution was always less than $0.5 \%$ and did not interfere with the contractile responses of the uterus. Sodium chloride $(\mathrm{NaCl})$ and sodium bicarbonate $\left(\mathrm{NaHCO}_{3}\right)$ (Merck), potassium chloride $(\mathrm{KCl})$, calcium chloride $\left(\mathrm{CaCl}_{2}\right)$ and glucose (Carlo Erba) were used for the preparation of physiological solutions, which were prepared freshly on the day of experiment.

\section{Extraction procedures}

Alkaloid extract from Carica papaya L. leaves was prepared as previously described [10]. In brief, the papaya leave powder $(2.2 \mathrm{~kg})$ was dampened thoroughly with concentrate ammonium hydroxide solution, and soaked in absolute methanol at room temperature for 3 days. This crude methanolic extract was then removed, filtered and stored at $4{ }^{\circ} \mathrm{C}$. The extraction of the remaining leave powder with methanol was repeated until trace of alkaloid in the extracts as detected by Dragendroff's reagent showed negative results. All methanolic extracts from this step were then combined, and evaporated until dryness under reduced pressure at $50{ }^{\circ} \mathrm{C}$ using Rotavac Evaporator $\left(\mathrm{Buchi}^{{ }^{\circledR}}\right)$. The extract was then dissolved in aqueous sulfuric acid solution ( $2 \%$ in distilled water), extracted with $n$-hexane to remove extractable materials such as fat materials and oils and the hexane fraction was discarded. The $\mathrm{pH}$ of aqueous fraction was then raised to $\mathrm{pH} 9$ using ammonium hydroxide solution. This fraction was then extracted with chloroform in excess. The chloroform extracts were then combined and dry at $50^{\circ} \mathrm{C}$ under reduced pressure. The crude alkaloid extract obtained from the last step was partially purified by dissolving in aqueous sulfuric acid solution ( $2 \%$ sulfuric acid in water) and the alkaloid extraction procedure were repeated as described above. The crude alkaloid extracts $(9.1 \mathrm{~g})$ were obtained and stored in an air tight bottle at $4{ }^{\circ} \mathrm{C}$ until use.

\section{Experimental animals}

Female Wistar rats, age 2 - 3 months (weighing between 200 - 300 gm.) were obtained from Southern Animal Facility, Animal House Unit, Faculty of Science, Prince of Songkla University, Songkhla, Thailand. All animal protocols in this study were approved by the Institutional Animals Care and Use Committee, Prince of Songkla University (REF 24/51). They were housed in environmental 
controlled-room (relative humidity 55 - $60 \%$, temperature $24-26^{\circ} \mathrm{C}$ and $12 \mathrm{~h}$ light/dark cycle). The rats were given intraperitoneally with diethylstilbestrol (DES) $(100 \mu \mathrm{g}) 24 \mathrm{~h}$ before the experiment.

\section{Experimental protocols}

On the day of experiment, the rats were euthanized by cervical dislocation. Both sides of myometrium were removed and submerged in Jalon-Ringer solution. The myometrial strips were cleared of adipose tissues, ovary, and other connective tissues and cut into a strip of about $1 \mathrm{~cm}$ in length. A myometrial strip was then placed in a $20 \mathrm{~mL}$-double jacket organ chamber pre-filled with normal physiological salt solution, Jalon-Ringer solution, containing (in $\mathrm{mM}$ ) $154.0 \mathrm{NaCl}, 5.63 \mathrm{KCl}, 0.648$ $\mathrm{CaCl}_{2}, 5.95 \mathrm{NaHCO}_{3}$ and 2.77 Glucose. In some experiments, other physiological solutions were required as indicated in experimental procedures. Their compositions were as follows: 1) Lock-Ringer solution (in $\mathrm{mM}) 154.0 \mathrm{NaCl}, 5.63 \mathrm{KCl}, 2.16 \mathrm{CaCl}_{2}, 5.95 \mathrm{NaHCO}_{3}, 2.10 \mathrm{MgCl}_{2}$ and 5.55 Glucose 2) Depolarizing solution (in mM) $103.3 \mathrm{NaCl}, 56.3 \mathrm{KCl}, 0.648 \mathrm{CaCl}_{2}, 5.95 \mathrm{NaHCO}_{3}$ and 2.77 Glucose and 3) $\mathrm{Ca}^{2+}$-free solution (similar to depolarizing solution but lacking $\mathrm{CaCl}_{2}$ ) (in $\mathrm{mM}$ ) $103.3 \mathrm{NaCl}, 56.3 \mathrm{KCl}, 5.95$ $\mathrm{NaHCO}_{3}, 2.77$ Glucose and 0.01 EDTA. These solutions were saturated with carbogen $\left(95 \% \mathrm{O}_{2}, 5 \%\right.$ $\mathrm{CO}_{2}$ ) and the temperature was kept constantly at $37{ }^{\circ} \mathrm{C}$ throughout the experiment. The myometrial strip was then fixed in position in the organ chamber and connected to force displacement transducer (Grass Instrument Co.) to record the contractile responses isometrically on the adjoining Grass polygraph. The myometrial strip was equilibrated at initial tension of $2 \mathrm{~g}$ for at least $1 \mathrm{~h}$ during which the medium was changed every $15 \mathrm{~min}$. The medium was changed to fresh medium before the experiment was begun. In all experiments, a myometrial strip from the other uterine horn of the same animal was also set up in parallel to serve as a control treatment to compare with the drug effect. This myometrial strip was prepared with similar procedures to the drug treated strip, but the relevant vehicle of the drug being tested was used to substitute the drug solution. In all experiments which multiple concentrations of drug were tested in the same myometrial strip, an appropriate amount of drug was added to the organ chamber cumulatively to achieve each concentration as required.

\section{Experimental procedures}

Effect of papaya alkaloid $(P A)$ on myometrial contraction

After the myometrial strip was equilibrated for $1 \mathrm{~h}, \mathrm{PA}\left(10^{-6}-10^{-3} \mathrm{gm} / \mathrm{mL}\right)$ were added cumulatively to the organ chamber. Changes in myometrial tension were then recorded.

\section{Effect of PA on myometrium pre-contracted with depolarizing solution}

After the myometrial strip was equilibrated for $1 \mathrm{~h}$, Jalon-Ringer solution in the organ chamber was changed to a depolarizing solution to induce contraction of the myometrial strip [11]. When the contraction reached the maximum plateau, PA $\left(10^{-6}-10^{-3} \mathrm{gm} / \mathrm{mL}\right)$ were added to the organ chamber. The contractile response caused by each concentration of PA was permitted to develop maximally before adding the next concentration of PA. The control myometrial strip was tested in parallel by the addition of PA vehicle. Changes in myometrial tension were then recorded.

Effect of $\mathrm{PA}$ and verapamil on myometrial contraction produced by $\mathrm{CaCl}_{2}$ in $\mathrm{Ca}^{2+}$-free solution

After the myometrial strip was equilibrated for $1 \mathrm{~h}$, the medium was replaced by $\mathrm{Ca}^{2+}$-free solution [11]. This solution was replaced by fresh solution every $10 \mathrm{~min}$ until the tension returned to baseline. $\mathrm{CaCl}_{2}\left(10^{-5}-3 \times 10^{-2} \mathrm{M}\right)$ were then added to the organ chamber. When the maximum contraction was achieved, the myometrial strip was then washed with $\mathrm{Ca}^{2+}$-free solution for many times until the myometrial tension return to baseline. The myometrial strip was then pre-incubated in PA $\left(10^{-5} \mathrm{gm} / \mathrm{mL}\right)$ or verapamil $\left(10^{-9} \mathrm{M}\right)$ for $15 \mathrm{~min}$ and cumulative concentrations of $\mathrm{CaCl}_{2}\left(10^{-5}-3 \times 10^{-2} \mathrm{M}\right)$ were added. The contractile response to each concentration of $\mathrm{CaCl}_{2}$ were recorded. This experiment was repeated but the concentration of PA was changed to $3 \times 10^{-5}$ and $10^{-4} \mathrm{M}$ or verapamil at $10^{-8}$ and $10^{-7} \mathrm{M}$.

\section{Effect of PA on myometrial contractility induced by uterine stimulants}

The myometrial strip was incubated in Lock-Ringer solution for $1 \mathrm{~h}$ at $37{ }^{\circ} \mathrm{C}$. Myometrial contraction was induced by the addition of either oxytocin $(1 \mathrm{mU} / \mathrm{mL})$, acetylcholine $\left(3 \times 10^{-5} \mathrm{M}\right)$ or $\mathrm{PGF}_{2 \alpha}\left(10^{-5} \mathrm{M}\right)$. After the contractile responses to the stimulants were stable, cumulative concentrations of PA $\left(10^{-6}-10^{-3} \mathrm{gm} / \mathrm{mL}\right)$ were added to the organ chamber. The contractile responses of myometrium to each concentration of PA were permitted to develop maximally before the addition of the next concentration. The control myometrial strip was performed in parallel. Changes in myometrial tension were then recorded. 


\section{Effect of $\beta$-adrenergic receptor antagonist on myometrial relaxation produced by $P A$ or isoproterenol}

After equilibration for $1 \mathrm{~h}$, the myometrial strip was induced to contract by exchanging the solution in the organ chamber to a depolarizing solution. After tonic contraction plateau was achieved, cumulative concentrations of PA $\left(10^{-6}-10^{-3} \mathrm{gm} / \mathrm{mL}\right)$ or isoproterenol $\left(10^{-10}-10^{-5} \mathrm{M}\right)$ were added to the organ chamber and the contractile responses of the myometrial strip were recorded. The myometrial strip was then washed for many times with Jalon-Ringer solution. The procedures were then repeated but the myometrial strip was incubated for $20 \mathrm{~min}$. with propranolol $\left(10^{-7} \mathrm{M}\right)$, a non-selective $\beta$-adrenergic receptor antagonist, before the addition of isoproterenol or PA. The control strip was performed in parallel. The myometrial tension caused by PA or isoproterenol with or without propranolol was then recorded.

\section{Data analysis}

The responses of the myometrium were analyzed as changes in isometric tension and calculated as percentage of maximum contraction induced by the uterine stimulants. The results were expressed in term of mean \pm standard error of mean (mean \pm S.E.M.). The $\mathrm{IC}_{50}$ (half maximal inhibitory concentration) was calculated from a plot of log concentration vs. the percentage of maximum contraction response in individual experiment. Repeated measure ANOVA and Duncan's multiple range test were used for statistical analysis. A significant difference will be determined when $p$ is less than 0.05 .

\section{Results and discussion}

Effect of papaya alkaloid (PA) on myometrial contraction

Cumulative concentrations of PA $\left(10^{-6}-10^{-3} \mathrm{gm} / \mathrm{mL}\right)$ had no effects on the myometrial strip as observed by no changes in resting tension of the myometrial strip to each concentration of PA (data not shown).

\section{Effect of PA on myometrium pre-contracted with depolarizing solution}

In the control treatment, the vehicle of PA had no effects on the contractile response of the myometrial strip produced by depolarizing solution. On the contrary, PA $\left(10^{-6}-10^{-3} \mathrm{gm} / \mathrm{mL}\right)$ inhibited the contraction of myometrial strip in a concentration-dependent fashion. The inhibition occurred significantly with PA at the concentration of $10^{-5}-10^{-3} \mathrm{gm} / \mathrm{mL}$ while PA at the concentration of $10^{-3} \mathrm{gm} / \mathrm{ml}$ caused the myometrial strip to relax completely. The $\mathrm{IC}_{50}$ of PA was $8.37 \pm 0.58 \times 10^{-5} \mathrm{gm} / \mathrm{mL}$. The concentration-response curve of PA on myometrial contraction induced by depolarizing solution was shown in Figure 1.

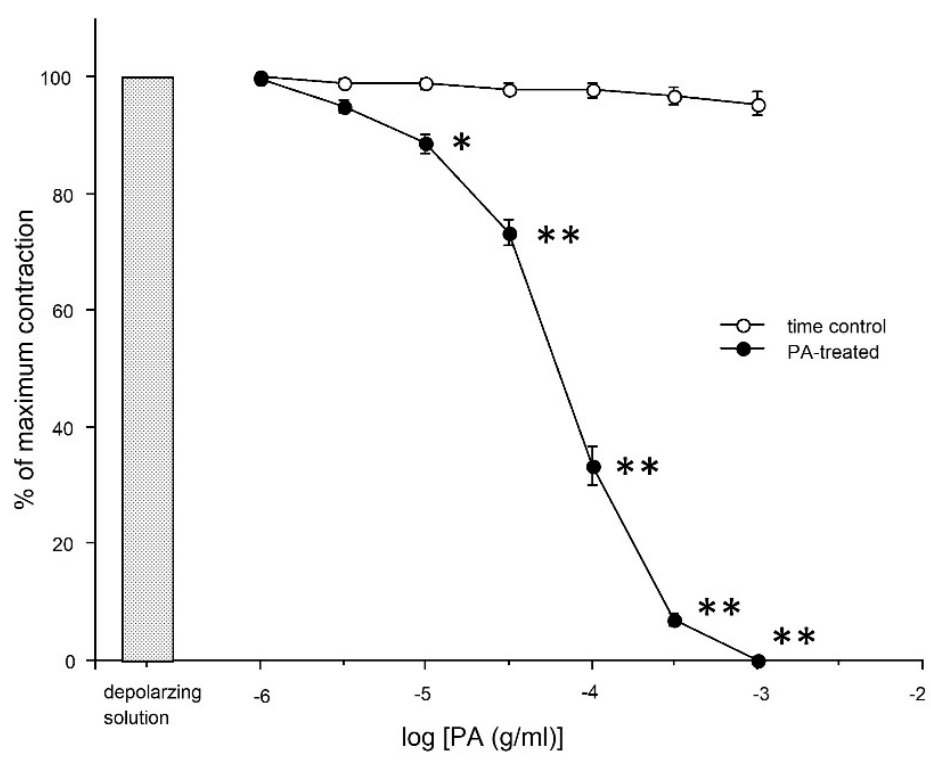

Figure 1 The concentration-response relationship of PA in myometrial strip with depolarizing solutioninduced contraction. Each data point expressed as the mean \pm S.E. of 8 experiments. $(*=p<0.05, * *=p$ $<0.01$ as compared to the control). 


\section{solution}

Effect of $\mathrm{PA}$ and verapamil on myometrial contraction produced by $\mathrm{CaCl}_{2}$ in $\mathrm{Ca}^{2+}$-free

In $\mathrm{Ca}^{2+}$-free solution, the addition of $\mathrm{CaCl}_{2}\left(10^{-5}-3 \times 10^{-2} \mathrm{M}\right)$ caused the myometrium to contract in a concentration-dependent fashion. The presence of PA $\left(10^{-5}, 3 \times 10^{-5}\right.$ and $\left.10^{-4} \mathrm{gm} / \mathrm{mL}\right)$ inhibited the contraction significantly $\left(p<0.05\right.$ for $10^{-5} \mathrm{gm} / \mathrm{mL}, p<0.01$ for $3 \times 10^{-5} \mathrm{gm} / \mathrm{mL}$ and $p<0.01$ for $10^{-4}$ $\mathrm{gm} / \mathrm{mL}$ ). The concentration-response curves of $\mathrm{CaCl}_{2}$ were shifted rightward and the maximum contraction was decreased. $\mathrm{EC}_{50}$ of $\mathrm{CaCl}_{2}$ alone was $4.74 \pm 0.68 \times 10^{-4} \mathrm{M}$, but the value was changed to $1.38 \pm 0.17 \times 10^{-3}(p<0.05), 2.60 \pm 0.26 \times 10^{-3}(p<0.01)$ and $7.50 \pm 0.44 \times 10^{-3} \mathrm{M}(p<0.01)$ in response to the presence of PA at $10^{-5}, 3 \times 10^{-5}$ or $10^{-4} \mathrm{gm} / \mathrm{mL}$, respectively. Likewise, the myometrial contraction induced by $\mathrm{CaCl}_{2}$ was also suppressed by verapamil in a concentration-dependent fashion. In the presence of verapamil $\left(10^{-9}, 10^{-8}\right.$ and $\left.10^{-7} \mathrm{M}\right)$, the myometrial contraction produced by $\mathrm{CaCl}_{2}$ were inhibited significantly $\left(p<0.05\right.$ for $10^{-9} \mathrm{M}, p<0.05$ for $10^{-8} \mathrm{M}$ and $p<0.05$ for $10^{-7} \mathrm{M}$, as compared to the tension in the absence of verapamil). The concentration-response curves produced by $\mathrm{CaCl}_{2}\left(10^{-5}-3 \times 10^{-2} \mathrm{M}\right)$ were shifted rightward whilst the maximum contraction was also decreased in comparison to the effect of only $\mathrm{CaCl}_{2}$. $\mathrm{EC}_{50}$ of $\mathrm{CaCl}_{2}$ alone was $5.59 \pm 1.78 \times 10^{-4} \mathrm{M}$, but the value was elevated significantly to 1.20 $\pm 0.26 \times 10^{-3} \mathrm{M}(p<0.05), 2.51 \pm 0.11 \times 10^{-3}(p<0.01)$, and $5.83 \pm 0.15 \times 10^{-3}(p<0.01)$ in the presence of verapamil $10^{-9}, 10^{-8}$ or $10^{-7} \mathrm{M}$, respectively. The log concentration-response relationship of $\mathrm{CaCl}_{2}$ with or without PA or verapamil at various concentrations were illustrated in Figure 2.

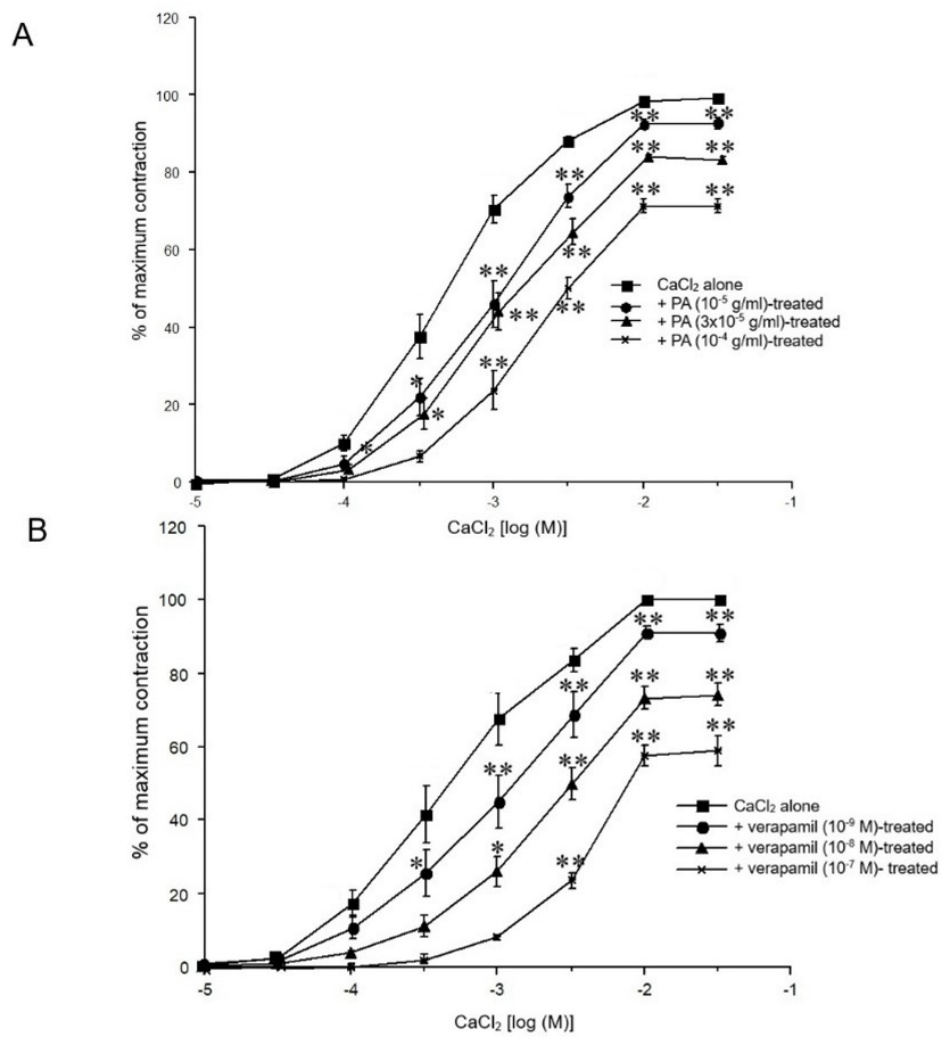

Figure 2 The concentration-response relationship of $\mathrm{CaCl}_{2}\left(10^{-5}-3 \times 10^{-2} \mathrm{M}\right)$-induced contraction in myometrium with or without A) PA, or B) verapamil. The data were expressed in term of mean \pm S.E. of 8 experiments. $\left(*=p<0.05, * *=p<0.01\right.$ when compare to the effect of $\mathrm{CaCl}_{2}$ alone).

Effect of PA on myometrial contraction induced by oxytocin, $\mathrm{PGF}_{2 \alpha}$ or acetylcholine

In the control group, oxytocin $(1 \mathrm{mU} / \mathrm{mL}), \operatorname{PGF}_{2 \alpha}\left(10^{-5} \mathrm{M}\right)$ or acetylcholine $\left(3 \times 10^{-5} \mathrm{M}\right)$ induced a phasic contraction of the uterus of which the amplitude was steady throughout the experiment. The vehicle of PA had no effects on the contractile responses produced by these stimulants. On the contrary, PA $\left(10^{-6}-10^{-3} \mathrm{gm} / \mathrm{mL}\right)$ significantly inhibited the amplitude of contraction induced by either oxytocin, 
$\mathrm{PGF}_{2 \alpha}$ or acetylcholine. The concentration-response relationship of PA on the myometrial contractility produced by oxytocin, $\mathrm{PGF}_{2 \alpha}$ or acetylcholine were illustrated in Figure 3, $\mathrm{IC}_{50}$ values of PA on the contraction of myometrial strip pre-contracted with oxytocin, $\mathrm{PGF}_{2 \alpha}$ or acetylcholine were $7.39 \pm$ $1.35 \times 10^{-5}, 8.27 \pm 1.80 \times 10^{-5}$ or $6.07 \pm 1.43 \times 10^{-5} \mathrm{gm} / \mathrm{mL}$, respectively.

A.

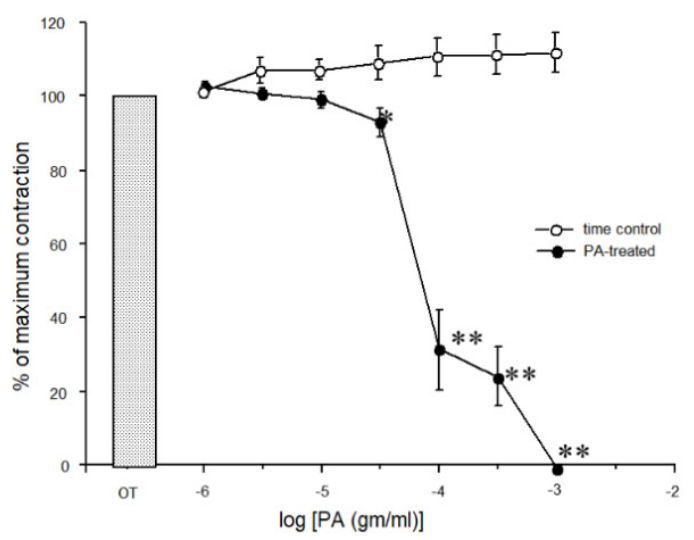

B.

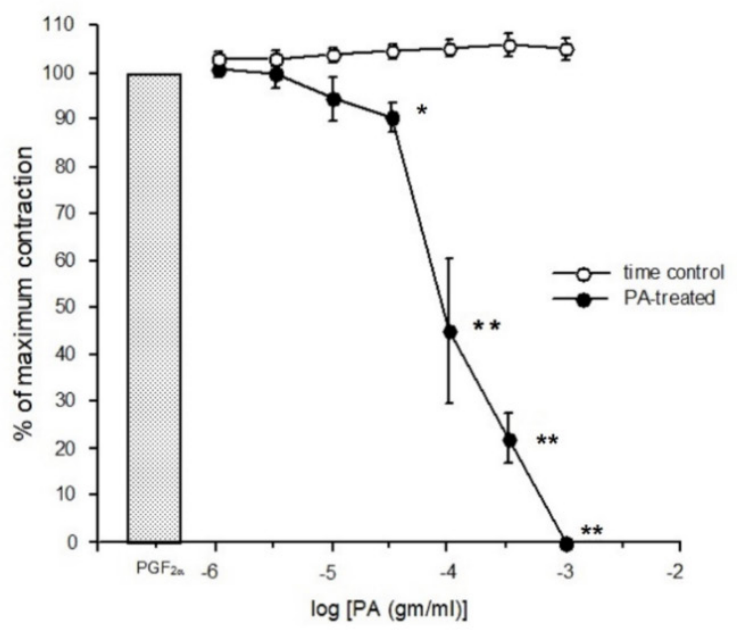

C.

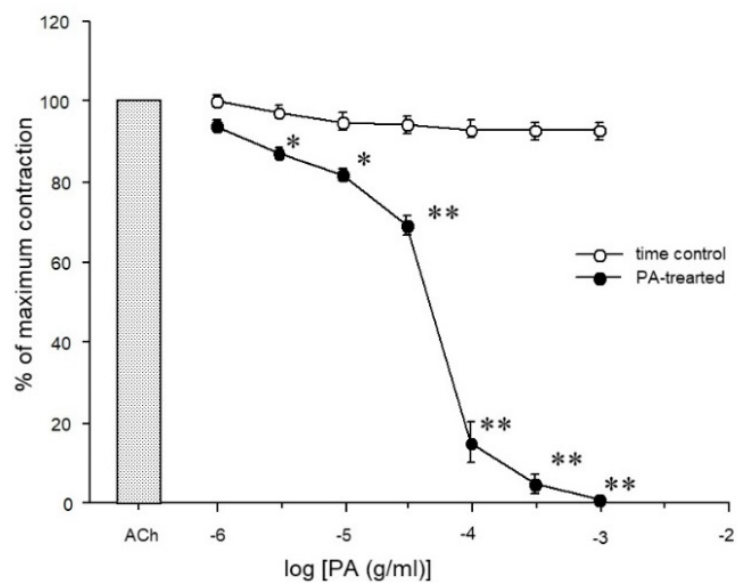

Figure 3 The concentration-response relationship of PA on myometrium contraction produced by A) oxytocin $(1 \mathrm{mU} / \mathrm{mL}), \mathrm{B}) \mathrm{PGF}_{2 \alpha}\left(10^{-5} \mathrm{M}\right)$ or $\left.\mathrm{C}\right)$ acetylcholine $\left(3 \times 10^{-5} \mathrm{M}\right)$. The data was expressed in term of mean \pm S.E. of 8 experiments $\left({ }^{*} p<0.05,{ }^{* *} p<0.01\right.$ in comparison to the respective control). 


\section{Effect of propranolol on myometrial relaxation induced by PA or isoproterenol}

This experiment was performed initially by inducing the uterus to contract by depolarizing solution. This tonic contraction when the maximum plateau was achieved was stable throughout the experimental period. The addition of vehicle of PA or isoproterenol produced no effects on this contraction. The addition of PA $\left(10^{-6}-10^{-3} \mathrm{gm} / \mathrm{mL}\right)$ inhibited the contraction with $\mathrm{IC}_{50}$ of $6.28 \pm 0.62 \times 10^{-4} \mathrm{gm} / \mathrm{mL}$. In the presence of propranolol $\left(10^{-7} \mathrm{M}\right)$, PA also suppressed the contraction with $\mathrm{IC}_{50}$ of $6.35 \pm 0.32 \times 10^{-4} \mathrm{gm} / \mathrm{mL}$ which was not significant difference from the effect in the absence of propranolol $(p>0.05)$. The addition of isoproterenol $\left(10^{-10}-10^{-5} \mathrm{M}\right)$ appeared to inhibit the myometrial contractility in a concentration-dependent fashion with $\mathrm{IC}_{50}$ of $1.39 \pm 0.23 \times 10^{-9} \mathrm{M}$. The presence of propranolol $\left(10^{-7} \mathrm{M}\right)$ diminished the activity of isoproterenol significantly $(p<0.01)$ as noted by the rightward shift of concentration-response curve of isoproterenol with $\mathrm{IC}_{50}$ of $1.72 \pm 0.38 \times 10^{-6} \mathrm{M}$. The plot of concentrationresponse relationship of PA or isoproterenol in the absence or presence of propranolol $\left(10^{-7} \mathrm{M}\right)$ were illustrated in Figure 4.

A

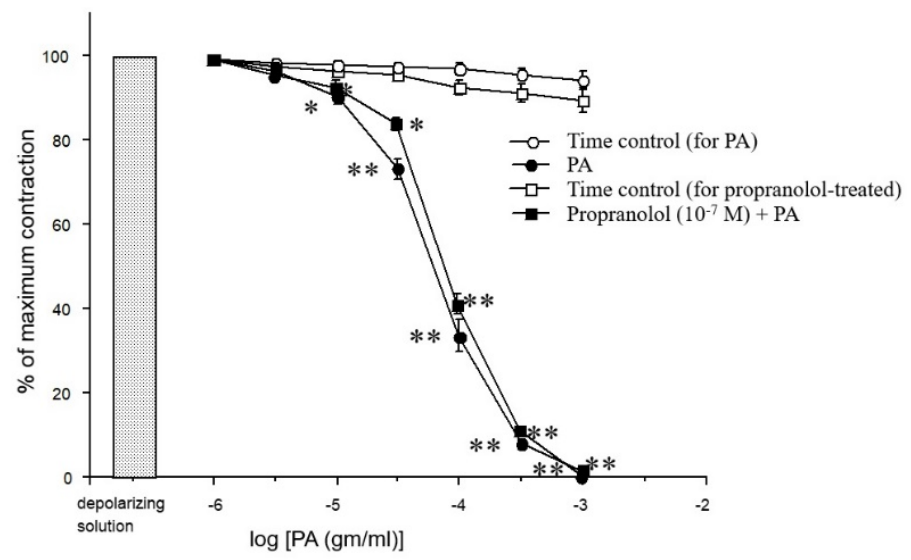

B

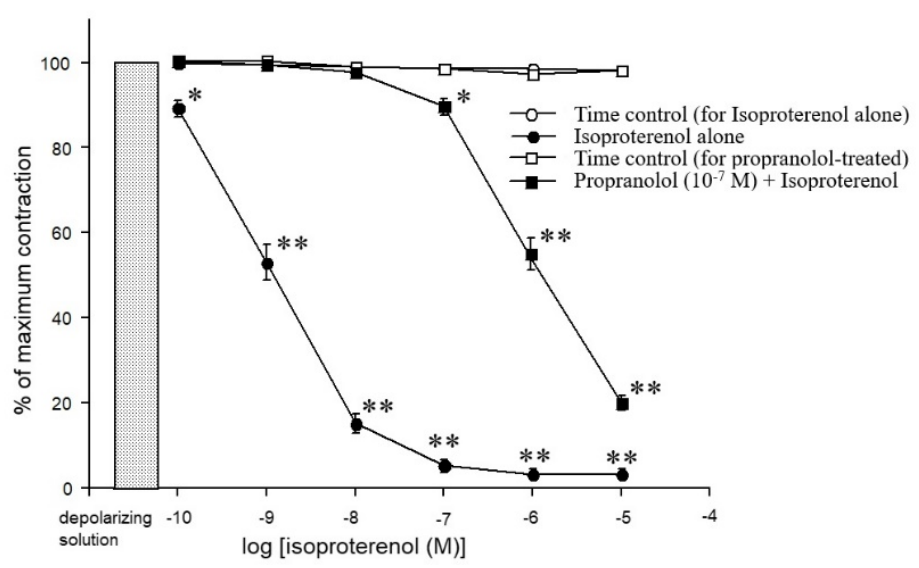

Figure 4 The concentration-response relationship of PA A) or isoproterenol B) and myometrial relaxation in the absence or presence propranolol $\left(10^{-7} \mathrm{M}\right)$ in depolarizing solution-contracted myometrium. The data were expressed in term of mean \pm S.E. of 8 experiments. $(* p<0.05, * * p<0.01$ in comparison to the control).

\section{Discussion}

The aim of this study is to demonstrate the action and possible mechanism of papaya alkaloid (PA) on the rat myometrium. The crude alkaloid extract $(9.1 \mathrm{gm})$ was prepared by a single extraction and used throughout this study. The yield of crude alkaloid extract was approximately $0.414 \%$ of the dried leaves weight. Carpaine was reported to be a principal alkaloid of Carica papaya L. which was found to be present $0.52 \%$ in shade-dried leaves [12]. Apart from carpaine, pseudocarpaine, dehydrocarpaine I and II have been found in papaya leaves [2,3], however, the yield of these alkaloids has not been published. 
Our preliminary finding showed that PA had no effect on myometrial contraction. However, PA was able to completely inhibit myometrial contraction produced by depolarizing solution and caused a rightward shift of concentration-response curve of $\mathrm{CaCl}_{2}$. It is suggested that the effect of PA may involve a decrease in $\mathrm{Ca}^{2+}$ entry into the myometrial muscle cells. Furthermore, the relaxing activity of PA on $\mathrm{CaCl}_{2}$-induced myometrial contraction in $\mathrm{Ca}^{2+}$-free solution is resemble to the effect of a calcium channel antagonist, verapamil [13]. It is suggested that the inhibitory effect of PA on $\mathrm{Ca}^{2+}$ entry through voltagedependent $\mathrm{Ca}^{2+}$-channel may occur in the same fashion as verapamil.

It is well established that the uterus contains various specific receptors for many classes of myometrial stimulants and myometrial relaxants. Oxytocin, $\mathrm{PGF}_{2 \alpha}$ and $\mathrm{ACh}$ are known to be naturaloccurring myometrial stimulants. The interaction of these stimulants on their own receptors on uterus (OXTR for oxytocin, FP receptor for $\mathrm{PGF}_{2 \alpha}$, and $\mathrm{M} 2$ and $\mathrm{M} 3$ receptor for $\mathrm{ACh}$ ) can induce myometrial contraction [14]. At present, there are no known agonists or antagonists that can cross-react with these 3 types of receptors. PA appeared to be a general uterine relaxant which was able to inhibit myometrial contraction caused by those stimulants as well as depolarizing solution and $\mathrm{CaCl}_{2}$. It seems unlikely that PA could produce the effect by interfering the binding of those stimulants to their receptors.

Our results have shown that $\mathrm{PA}$ inhibited $\mathrm{K}^{+}$-induced uterine contraction using depolarizing solution. It also inhibited the contraction induced by cumulative concentrations of $\mathrm{CaCl}_{2}$ in $\mathrm{Ca}^{2+}$-free solution $\left(\mathrm{K}^{+}\right.$-depolarized uterus) similar to that occur by verapamil. These results suggested that the uterine relaxing effect of PA may involve mainly $\mathrm{Ca}^{2+}$ influx, probably via voltage-operated calcium channels.

The action of oxytocin, $\mathrm{PGF}_{2 \alpha}$ and $\mathrm{ACh}$ which induce the myometrium to contract is the result of an increase in intracellular $\mathrm{Ca}^{2+}$ from both $\mathrm{Ca}^{2+}$-release from internal storage and probably $\mathrm{Ca}^{2+}$-entry via plasma membrane [14-16]. The action of oxytocin, $\mathrm{PGF}_{2 \alpha}$ and $\mathrm{ACh}$ which induced $\mathrm{Ca}^{2+}$-release from internal storage are postulated to be meditated by $\mathrm{IP}_{3}$ signaling pathway. It is well known that all receptors of oxytocin, $\mathrm{PGF}_{2 \alpha}$ and $\mathrm{ACh}$ are G-protein-coupled receptors $\left(\mathrm{G}_{\mathrm{q}}\right.$ subtype) [17,18]. The interaction between these agonists to their receptors on plasma membrane activates G-protein coupled to phospholipase $\mathrm{C}$ that causes the hydrolysis of $\mathrm{PIP}_{2}$ to $\mathrm{IP}_{3} . \mathrm{IP}_{3}$ will then activate its receptor on sarcoplasmic reticulum resulting in $\mathrm{Ca}^{2+}$-release from internal storage. The evidence has shown that the effect of oxytocin is mediated through the hydrolysis of $\mathrm{PIP}_{2}$ to $\mathrm{IP}_{3}$ to induce $\mathrm{Ca}^{2+}$ release. Nevertheless, the contractile effect of oxytocin is noticeably suppressed by verapamil, a $\mathrm{Ca}^{2+}$ channel blocker [19]. It is indicated that an increase in $\mathrm{Ca}^{2+}$ entry from extracellular space through L-type voltage-dependent $\mathrm{Ca}^{2+}$ channel mediated mainly the action of oxytocin to cause myometrium contraction. A recent study suggested that oxytocin open the voltage-operated calcium channels indirectly via the opening of other cation channels such as $\mathrm{Ca}^{2+}$-activated $\mathrm{Cl}^{-}$channels or capacitative $\mathrm{Ca}^{2+}$ entry which cause depolarization and open the calcium channel [16]. In addition, oxytocin-induced $\mathrm{Ca}^{2+}$ influx have been shown to be involved several $\mathrm{Ca}^{2+}$ channels in human myometrial cells such as transient receptor potential cation channels (TrpC)1, TrpC3, TrpC4, and TrpC6 [20]. The present of these channels in rat myometrial cells has yet to be determined. If they are present, these channels may contribute to a rise in intracellular $\mathrm{Ca}^{2+}$ in rat myometrial cells and might be the target to cause the effect of PA. Although, the involvement of $\mathrm{PGF}_{2 \alpha}$ and $\mathrm{ACh}$ to stimulate the $\mathrm{Ca}^{2+}$ entry via the opening of voltage-operated calcium channels is unclear, $\mathrm{Ca}^{2+}$ entry via these channels is essential for myometrium contraction [15].

The $\beta$-adrenergic receptors in the myometrium are mainly of $\beta_{2}$-subtype and the activation of $\beta_{2}$ receptors cause myometrial relaxation [21]. The present study has shown that nonspecific $\beta$-adrenergic receptor agonist, isoproterenol $\left(10^{-10}-10^{-5} \mathrm{M}\right)$, caused relaxation of $\mathrm{KCl}$-depolarized myometrium in a concentration-dependent fashion, and this effect was abolished by pretreatment with a $\beta$-adrenergic receptor antagonist propranolol $\left(10^{-7} \mathrm{M}\right)$. PA alone caused a relaxation of the $\mathrm{KCl}$-depolarized uterus similar to the effect of isoproterenol. Although propranolol $\left(10^{-7} \mathrm{M}\right)$ was able to inhibit the effect of isoproterenol, it produced no effect on the relaxation activity caused by PA. This result suggested that the myometrial relaxation caused by PA may be unrelated to the interaction of PA on $\beta_{2}$-adrenergic receptor.

$\beta_{2}$-adrenergic receptor is known to be a G-protein coupled receptor of the Gs subtype. The interaction of $\beta$-adrenergic agonist on this receptor causes the stimulation of adenylate cyclase which accelerates the conversion of ATP to cAMP. The rise in intracellular cAMP then activates cAMPdependent kinase which phosphorylates proteins and causes myometrial relaxation [14]. The termination of the effect occurred by the hydrolysis of cAMP. This reaction is catalyzed by several phosphodiesterase (PDE) which convert cAMP to 5'AMP [22]. The inhibition of this enzyme by PDE inhibitor may cause a rise in intracellular cAMP leading to myometrial relaxation [23]. Although the effect of PA is unlikely to be mediated via $\beta_{2}$-adrenergic receptor activation, a PDE inhibition may be the site of action of PA. In 
addition, other intracellular sites such as the contractile machinery of which its activity is downstream after the interaction of $\mathrm{Ca}^{2+}$ to calmodulin may be the site of action of PA to cause uterine muscle relaxation.

\section{Conclusions}

The results of this study indicate that PA is a myometrial relaxant. The myometrial relaxation effect of PA is unlikely to be mediated by an activation of $\beta_{2}$-adrenergic receptor. The effect of PA may involve an inhibition of a rise in intracellular $\mathrm{Ca}^{2+}$ from both $\mathrm{Ca}^{2+}$ release from internal storage and $\mathrm{Ca}^{2+}$ entry via plasma membrane. This action may be mediated predominantly by a reduction on $\mathrm{Ca}^{2+}$ influx, possibly by an inhibition on voltage-operated $\mathrm{Ca}^{2+}$ channel. However, the precise mechanism for the relaxing effect of PA is awaited to be determined.

\section{References}

[1] A Ali, S Devarajan, MI Waly, MM Essa and MS Rahman. Nutritional and medicinal values of papaya (Carica papaya L.). In: MM Essa, A Manickavasagan and E Sukumar (Eds.). Natural products and their active compounds on disease prevention. Nova Science Publishers, New York, 2012, p. 307-24.

[2] A Roshan, NK Verma and A Gupta. A brief study on Carica papaya- A review. Int. J. Cur. Tren. Pharm. Res. 2014; 2, 541-50.

[3] PS Swarkar. A review on: Carica papaya used as herbal medicine in Primary dysmenorrhea. Int. J. Sci. Res. Publ. 2020; 10, 873-80.

[4] SP Singh, S Kumar, SV Mathan, MS Tomar, RK Singh, PK Verma, A Kumar, S Kumar, RP Singh and A Acharya. Therapeutic application of Carica papaya leaf extract in the management of human diseases. Daru J. Pharm. Sci. 2020; 28, 735-44.

[5] SN Abidah, S Hadisaputro, Runjati, ST Hidayat and A Suwondo. Effect of Carica papaya L. leaf on Menstrual pain and prostaglandin level in adolescent with primary dysmenorrhea: A true experiment. Belitung Nurs. J. 2017; 3, 198-204.

[6] EM Burdick. Carpaine: An alkaloid of Carica papaya - its chemistry and pharmacology. Econ. Botany 1971; 25, 363-5.

[7] CA Hurnick, LI Sanders and YC Lin. Effect of carpaine, a papaya alkaloid, on the circulatory function in the rat. Res. Comm. Clin. Path. Pharmacol. 1978; 22, 277-89.

[8] V Zunjar, RP Dash, M Jivrajani, B Trivedi and M Nivsarkar. Antithrombocytopenic activity of carpaine and alkaloidal extract of Carica papaya Linn. leaves in busulfan induced thrombocytopenic Wistar rats. J. Ethnopharmacol. 2016; 181, 20-5.

[9] T Julianti, MD Mieri, S Zimmermann, SN Ebrahimi, M Kaiser, M Neuburger, M Raith, R Brun and M Hamburger. HPLC-based activity profiling for antiplasmodial compounds in the traditional Indonesian medicinal plant Carica papaya L. J. Ethnopharmacol. 2014; 155, 426-34.

[10] GA Cordell. Introduction to alkaloids. John Wiley \& Sons, New York, 1981, p. 9-25.

[11] C Perez-Guerrero, MD Herrera and E Marhuenda. Relaxant effect of tetrazepam on rat uterine smooth muscle: role of calcium movement. J. Pharm. Pharmacol. 1996; 48, 1169-73.

[12] S Haldar, S Mohapatra, R Singh and CK Katiyar. Isolation and quantification of bioactive Carpaine from Carica papaya L. and its commercial formulation by HPTLC densitometry. J. Liq. Chromatogr. Relat. Tech. 2020; 43, 11-2.

[13] WJ Elliott and CV Ram. Calcium channel blockers. J. Clin. Hypertens. (Greenwich) 2011; 13, 687-9.

[14] ER Levin, WS Vitek and SR Hammes. Estrogens, progestins, and the female reproductive tract. In: LL Brunton, R Hilal-Dandan and BC Knollmann (Eds.). Goodman \& Gilman's: The pharmacological basis of therapeutics. 13 ${ }^{\text {th }}$ ed. McGraw-Hill, New York, 2020.

[15] S Wray and C Prendergast. The myometrium: From excitation to contractions and labour. In: H Hashitani and R Lang (Eds.). Smooth muscle spontaneous activity, advances in experimental medicine and biology. Vol 1124. Springer Nature, Singapore, 2019, p. 233-63.

[16] S Arrowsmith and S Wray. Oxytocin: Its mechanism of action and receptor signalling in the myometrium. J. Neuroendocrinol. 2014; 26, 356-69.

[17] CW Gruber and M O'Brien. Uterotonic plants and their bioactive constituents. Planta. Med. 2011; 77, 207-20.

[18] J Brown, K Brandl and J Wess. Muscarinic receptor agonists and antagonists. In: LL Brunton, R Hilal-Dandan and BC Knollmann (Eds.). Goodman \& Gilman's: The pharmacological basis of therapeutics. $13^{\text {th }}$ ed. McGraw-Hill, New York, 2021. 
[19] EE Bafor, EK Omogbai and RI Ozolua. In vitro determination of the uterine stimulatory effect of the aqueous leaf extract of Ficus exasperata. J. Ethnopharmacol. 2010; 127, 502-7.

[20] B Jurek and ID Neumann. The oxytocin receptor: From intracellular signaling to behavior. Physiol. Rev. 2018; 98, 1805-908.

[21] TC Westfall, H Macarthur and DP Westfall. Adrenergic agonists and antagonists. In: LL Brunton, R Hilal-Dandan and BC Knollmann (Eds.). Goodman \& Gilman's: The pharmacological basis of therapeutics. $13^{\text {th }}$ ed. McGraw-Hill, New York, 2020.

[22] DK Blumenthal. Pharmacodynamics: Molecular mechanisms of drug action. In: LL Brunton, R Hilal-Dandan and BC Knollmann (Eds.). Goodman \& Gilman's: The pharmacological basis of therapeutics. $13^{\text {th }}$ ed. McGraw-Hill, New York, 2020.

[23] VM Munoz-Perez, E Fernandez-Martinez, H Ponce-Monter and MI Ortiz. Relaxant and antiinflammatory effect of two thalidomide analogs as PDE-4 inhibitors in pregnant rat uterus. Korean J. Physiol. Pharmacol. 2017; 21, 429-37. 